\title{
THE EFFECT OF TRAINING ON PREPAREDNESS DISASTER ON THE PREPAREDNESS OF ELEMENTARY SCHOOL CHILDREN IN OVERCOMINGTHE DISASTER OF VOLCANO ERUPTION OF MOUNT EGON IN LERE CATHOLIC ELEMENTARY SCHOOL
}

\author{
Yuliani Pitang ${ }^{1 *}$, Ode Irman ${ }^{2}$, Yosefina Nelista ${ }^{3}$ \\ 1,2,3 Teaching staff of The Health Sciences Faculty, Nusa Nipa University
}

\begin{tabular}{|c|c|}
\hline & ABSTRACT \\
\hline $\begin{array}{l}\text { Keywords: } \\
\text { elementary school } \\
\text { preparedness } \\
\text { preparedness } \\
\text { training diaster }\end{array}$ & $\begin{array}{l}\text { Mount eruption can happen at any time without warning including during teaching } \\
\text { learning proces in school time and the children are included into the the very sus- } \\
\text { ceptible group on disaster situation. Less preparedness causes the children be in } \\
\text { critical situation. To increase children's preparedness could be done through the } \\
\text { training on disaster preparedness in overcoming the disater caussed by volcano } \\
\text { eruption. The aim of this research is to explain The effect of Training on Prepared- } \\
\text { ness Disaster on The Preparedness of Elementary School Children in Overcoming } \\
\text { The Disaster of Volcano Eruption of Mount Egon in Lere Catholic Elementary School. } \\
\text { This research is classified as quasi experimental with the research design one pre } \\
\text { test post test design. The population on this research is all children of class IV and } \\
V \text { in Lere Catholic Elementary School. The total number is } 51 \text { children. Sampling } \\
\text { technique used is systematic random sampling. The total number of sampling is } 45 \\
\text { respondents. There is effect of training on disaster preparedness on the prepared- } \\
\text { ness of elementary school children in overcoming mount Egon eruption (p 0,000). } \\
\text { The training of disaster preparedness can increase on the preparedness of elemen- } \\
\text { tary school childen in overcoming the disaster of volcano eruption, therefore the } \\
\text { training of disaster preparedness needs to be done every year and to accommodate } \\
\text { the content of disaster in the school curriculum. }\end{array}$ \\
\hline
\end{tabular}

\section{ABSTRAK}

\section{Kata Kunci:}

anak sekolah dasar kesiapsiagaan pelatihan preparedness disaster
Letusan gunung dapat terjadi setiap saat tanpa peringatan, termasuk pada saat jam belajar dan anak termasuk dalam kelompok paling rentan dalam situasi bencana. Kurangnnya kesiapsiaagaan, menyebabkan anak berada dalam situasi krisis. Tingkat resiko bencana selain ditentukan oleh potensi bencana juga ditentukan oleh upaya mitigasi dan kesiapsiagaan dalam menghadapi bencana. Tujuan dalam penelitian ini adalah menjelaskan pengaruh pelatihan preparedness disaster terhadap kesiapsiagaan anak sekolah dasar dalam menghadapi bencana letusan gunung berapi Egon di SDK Lere. Jenis penelitian yang digunakan yaitu pre-experimental design dengan rancangan penelitian one pra test posttest design. Populasi dalam penelitian ini adalah semua siswa SD kelas IV dan V di SDK Lere berjumlah 51 orang. Sampling yang digunakan yaitu systematic random sampling. Besar sampel sebanyak 45 responden. Dengan menggunakan uji paired t-test menunjukan hasil Ada pengaruh pelatihan preparedness disaster terhadap kesiapsiagaan anak sekolah dasar dalam menghadapi letusan gunung berapi Egon ( $\mathrm{p} 0,000)$. Pelatihan preparedness disaster dapat meningkatkan kesiapsiagaan anak sekolah dasar dalam menghadapi bencana letusan gunung berapi. Pelatihan siaga bencana perlu di lakukan setiap tahun dan memasukan materi bencana ke dalam kurikulum. 


\section{PENDAHULUAN}

Bencana merupakan rangkaian peristiwa yang mengancam dan mengganggu kehidupan masyarakat yang disebabkan oleh faktor alam, faktor non alam maupun faktor manusia sehingga mengakibatkan timbulnya korban jiwa, kerusakan lingkungan, kerugian harta benda dan dampak psikologis (Listyaningsih, 2010). Salah satu jenis bencana alam antara lain berupa gunung meletus. Gunung meletus atau merapi menjadi bahaya karena dapat merugikan secara fisik, non fisik dan korban jiwa (Sudiharto, 2011). Bencana gunung meletus muncul ketika ancaman gunung berapi bertemu dengan masyarakat yang rentan yang mempunyai kemampuan rendah untuk menanggapi ancaman itu. Oleh karena itu, perlu adanya persiapan atau managemen bencana gunung berapi untuk mengurangi terjadinya korban jiwa dan kerugian harta dan benda (Listyaningsih, 2010).

Negara Indonesia merupakan salah satu negara dengan gunung berapi terbanyak di dunia dengan 400 gunung berapi, terdapat sekitar 192 buah gunung berapi yang masih aktif dan sepanjang 700 km mulai dari Aceh sampai Nusa Tenggara. Penyebaran gunung berapi di Indonesia saat ini sedang dalam kondisi yang membahayakan. Menurut Badan Nasional Penanggulangan Bencana, 1 gunung dalam status awas, 1 gunung dalam kondisi siaga, dan 16 gunung dalam status waspada (BNPB, 2018).

Gunung Egon merupakan salah satu gunung berapi aktif yang berada di kabupaten Sikka, Nusa Tenggara Timur. Secara geografis, puncak Gunung Egon berada pada $8^{\circ} 40^{\prime}$ Lintang Selatan dan $122^{\circ} 27^{\prime}$ Bujur Timur dengan tinggi 1703 meter di atas permukaan laut. Dalam catatan sejarah, dilaporkan bahwa pada periode $1888-1891$ dan pada 1892 teramati adanya kabut asap di puncak. Kemudian peningkatan aktivitas vulkanik juga tercatat 2 kali terjadi yaitu pada 28 September 1907 dimana terjadi letusan di kawah pusat dan pada tahun 1925 dimana terjadi semburan solfatara di kawah puncak bagian barat. Setelah 79 tahun tidak dilaporkan adanya peningkatan aktivitas, Gunung Egon kembali meletus mulai pada 28 Januari 2004. Letusan ini berlanjut pada Juli 2004 dan Agustus - September 2004. Letusan berikutnya terjadi pada 6-13 Februari 2005. Pada 15, 20, 24, dan 28 April 2008 kembali terjadi letusan.

Gunung berapi memberikan ancaman yang dapat menyebabkan bencana di wilayah lerengnya dan sekitarnya. Letusan gunung dapat terjadi setiap saat tanpa peringatan, termasuk pada saat jam belajar di sekolah (Tuswadi \& hayashi, 2014). Berdasarkan observasi di lapangan, SDK Lere merupakan salah satu sekolah dasar dengan radius paling dekat dengan lokasi gunung berapi Egon. Siswa masih memiliki kesiapsiagaan rendah dalam menghadapi bencana letusan gunung berapi. Pihak sekolah menjelaskan, upaya pengurangan resiko bencana masih minim dimana pelatihan terakhir yang diberikan oleh BPBD dilakukan 5 tahun yang lalu dengan hanya membagikan leaflet dan poster.

Sasaran yang ingin dicapai dalam penelitian ini adalah meningkatkan kesiapsiagaan anak sekolah dasar dalam menghadapi letusan gunung berapi Egon melalui pelatihan preparedness disaster. Mengingat anak termasuk dalam kelompok paling rentan dalam situasi bencana. Anak memiliki kemampuan yang terbatas untuk mengontrol atau mempersiapkan diri ketika merasa takut. Selain itu, semburan abu vulkanik akibat dari aktivitas vulkanik menimbulkan dampak baik secara fisik dan psikologis bagi anak.

\section{METODE}

Jenis penelitian yang digunakan yaitu pre experimentasl design dengan rancangan penelitian one pra test posttest design. Populasi dalam penelitian ini adalah semua siswa SD kelas IV dan V di SDK Lere berjumlah 51 orang. Sampling yang digunakan yaitu systematic random sampling. Besar sampel pada penelitian ini sebanyak 45 orang. Kriteria sampel pada penelitian ini yaitu: Kriteria inklusi dapat berkomunikasi dengan baik dan bersedia menjadi responden. Adapun kriteria ekslusi yaitu siswa/siswi tidak mengikuti proses penelitian hingga selesai. Berikut SOP pelaksanaannya.

Penelitian ini dilaksanakan di SDK LERE pada bulan September 2019. Penelitian dilaksanakan setelah mendapatkan kelayakan Etik dari Komisi Etik Penelitian Kesehatan (KEPK) Fakultas kedokteran Universitas Nusa Cendana Kupang, NTT dengan No.46/UN15.16/KEPK/2019 dan ijin dari pihak sekolah. Dalam proses penelitian, tim peneliti dibantu oleh BPBD Kabupaten Sikka. Instrumen yang digunakan adalah kuesioner yang diadopsi dari penelitian Herdwiyanti \& Sudaryono (2013) dan dimensi kesiapsiagaan bencana menurut Sutton \& Tierney (2006) sebanyak 23 item dengan skor masingmasing item 1-5, sehingga skor minimumnya 23 dan skor maksimumnya 115 . Uji validitas dilakukan terhadap 49 siswa dan dinyatakan valid dengan nilai $t$ hitung berkisar antara 0,517-0,889. Uji reliabilitas diperoleh nilai 0,773 artinya instrument tersebut reliable untuk digunakan sebagai alat ukur. Sebanyak 45 orang dilakukan pretest dengan mengisi kuesioner 
Tabel 1. SOP Pelatihan Preparedness Disaster

\begin{tabular}{ll}
\hline & STANDAR OPERASIONAL PROSEDUR \\
& Pelatihan preparedness disaster \\
\hline Tujuan: & Sebagai pedoman untuk melakukan pelatihan preparedness \\
Ruang Lingkup: & $\begin{array}{l}\text { Prosedur ini dipakai setiap melakukan pelatihan preparedness } \\
\text { dalam intervensi penelitian }\end{array}$ \\
Tanggung Jawab: & Tim Peneliti \\
Prosedur Kerja: & 1. Persiapan Responden \\
& a. Responden dikumpulkan dalam satu kelas \\
b. Mengisi daftar hadir \\
c. Jelaskan proses intervensi \\
2. Persiapan alat \\
a. LCD \\
b. Laptop \\
3. Pelaksanaan \\
a. Pejelasan diberikan oleh BPBD dan Tim peneliti \\
b. Waktu penjelasan 60-90 menit \\
c. Memberi kesempatan pada responden untuk bertanya \\
hal-hal yang belum dimengerti \\
d. Memberikan feedback kepada responden untuk melihat \\
sejauh mana pemahaman responden terhadap penjelasan \\
e. Mang diberikan \\
e. Membagikan kuesioner untuk diisi oleh responden
\end{tabular}

yang telah disiapkan. Setelah melakukan pretest, responden diberikan pelatihan oleh Tim Peneliti dan BPBD dalam bentuk simulasi dan video. Setelah melakukan pretest, responden diberikan pelatihan oleh Tim Peneliti dan BPBD dalam bentuk simulasi dan video. Intervensi dilaksanakan selama 60-90 menit di ruang kelas V SDK LERE, dimana semua siswa digabungkan menjadi satu kelompok. Pelatihan diberikan oleh Tim peneliti bersama BPBD setempat. Setelah melewati tahap pelatihan, responden kemudian melakukan posttest dengan mengisi kembali lembar kuesioner yang sama saat dilakukan pretest. Setelah melewati tahap pelatihan, responden kemudian melakukan posttest dengan mengisi kembali lembar kuesioner yang sama saat dilakukan pretest. Hasil uji normalitas data menunjukan nilai $\mathrm{p}$ pretest dan posttest $>0.05$ sehingga analisis data menggunakan uji paired t test.

\section{HASIL}

Responden dalam penelitian ini adalah siswa/ siswi SD kelas IV dan V rentang umur antara 10-12 tahun

Berdasarkan tabel 2 didapatkan bahwa jumlah siswa IV berjumlah 21 orang, kelas V berjumlah 24 orang, usia 10 tahun berjumlah 18 orang, 11 tahun berjumlah 19 orang dan 12 tahun berjumlah 8 orang, jenis kelamin laki-laki berjumlah 19 orang, perempuan 26 orang.

Berdasarkan tabel 3 nilai mean kesiapsiagaan bencana untuk pre 31.6 dan post 38.6

Berdasarkan uji statistik dengan menggunakan uji paired t-test menunjukkan nilai mean pre 31.6 dan nilai mean post 38.6. Nilai p value sebesar $0,000(<0.05)$ yang berarti ada pengaruh pelatihan preparedness disaster terhadap kesiapsiagaan anak sekolah dasar dalam menghadapi letusan gunung berapi Egon.

Jumlah responden dari kelas IV berjumlah 21 orang, sedangkan responden dari kelas V berjumlah 24 orang. Responden yang berusia 10 tahun berjumlah 18 orang,responden yang berusia 11 tahun berjumlah 19 orang, responden yang berusia 12 tahun berjumlah 8 orang. Responden dengan jenis kelamin laki-laki berjumlah 19 orang, responden dengan jenis kelamin perempuan berjumlah 26 orang.

Nilai mean kesipsiagaan responden pada tahap pre adalah 31.6 , sedangkan nilai mean kesiapsiagaan responden pada tahap post adalah 38.6

Tabel 4 menunjukkan nilai $\mathrm{p}=0.000$, nilai $\mathrm{p}<$ alfa (0.05), maka Ho di tolak dan Ha diterima jadi ada pengaruh pelatihan preparedness disaster terhadap kesiapsiagan anak sekolah dasar dalam menghadapi bencana letusan gunung berapi di SDK Lere. 
Tabel 2. Distribusi Karakteristik Demografi Responden

\begin{tabular}{lcc}
\hline \multicolumn{1}{c}{ Karakteristik Responden } & F & $\%$ \\
\hline Kelas & & \\
Kelas IV & 21 & 46.7 \\
Kelas V & 24 & 53.3 \\
Usia & & \\
$\quad 18$ Tahun & 19 & 40 \\
11 Tahun & 8 & 42.2 \\
$\quad 12$ Tahun & & 17.8 \\
Jenis Kelamin & 19 & 42.2 \\
$\quad$ Laki-Laki & 26 & 57.8 \\
$\quad$ Perempuan & & \\
\hline
\end{tabular}

Tabel 3. Distribusi Responden Berdasarkan Kesiapsiagan Bencana

\begin{tabular}{ccc}
\hline Kesiapsiagan & Mean & SD \\
\hline Pre & 31.6 & 7.05 \\
Post & 38.6 & 7.18 \\
\hline
\end{tabular}

Tabel 3. Pengaruh Pelatihan Preparedness Disaster Terhadap Kesiapsiagan Anak Sekolah Dasar

\begin{tabular}{cccc}
\hline Kesiapsiagan & Mean & SD & Nilai P \\
\hline Pre & 31.6 & 7.05 & 0.000 \\
Post & 38.6 & 7.18 & \\
\hline
\end{tabular}

\section{PEMBAHASAN}

Berdasarkan uji statistik dengan menggunakan uji paired t-test menunjukkan nilai mean pre 31.6 dan nilai mean post 38.6. Nilai $\mathrm{p}$ value sebesar $0,000(<0.05)$ yang berarti ada pengaruh pelatihan preparedness disaster terhadap kesiapsiagaan anak sekolah dasar dalam menghadapi letusan gunung berapi Egon. Kesiapsiagaan bencana merupakan serangkaian kegiatan yang dilakukan untuk mengantisipasi bencana melalui pengorganisasian serta melalui langkah yang tepat guna dan berdaya guna. Kesiapsiagaan adalah upaya yang dilaksanakan untuk mengantisipasi kemungkinan terjadinya bencana guna menghindari jatuhnya korban jiwa, kerugian harta benda, dan berubahnya tata kehidupan masyarakat (UU RI, No 24 tahun 2007). Salah satu cara yang dapat digunakan untuk menumbuhkan tindakan kesiapsiagaan siswa adalah dengan memberikan pelatihan dengan kombinasi penyajiannya melalui media animasi yang berisi tentang kesiaagan menghadapi bencana erupsi gunung api baik dari pra bencana hingga pasca bencana. Sekolah merupakan sarana dan wahana yang cukup efektif dalam menyebarkan informasi pengetahuan dan ketrampilan kepada masyarkat dalam hal ini siswa, dengan demikian, kegiatan pelatihan kebencanaan di sekolah menjadi efektif, dinamis, serta implementatif dalam upaya meningkatkan kemampuan warga sekolah khususnya siswa, untuk dapat mengurangi dampak resiko bencana di sekolah.

Hasil penelitian ini sejalan dengan penelitian yang dilakukan oleh Indriasari (2014) tentang pengaruh pelatihan siaga bencana gempa bumi terhadap kesiapsiagaan anak sekolah dasar, hasil ditunjukkan dengan nilai $p<0,001$, semua anak mampu dan terlibat setelah melakukan 5 kali simulasi sedangkan kesiapsiagaan anak dalam kategori kurang siap. Sebelum pelatihan sebanyak 22 anak (71\%) dan sesudah pelatihan meningkat menjadi 23 anak (76,7\%).Sejalan dengan peneltian yang dilakukan oleh Fitriyanti et.al (2019) yang menyatakan bahwa kesiapsiagaan akan meningkat dengan pemberian metode simulasi dan video animasi, hal ini dikarenakan para siswa/siswi selain langsung memperagakan bagaimana kesiapsiagaan bencana, video animasi yang ditampilkan menarik perhatian,sesuai dengan perkembangan umur anak sekolah dasar sehingga 
mudah terserap dengan baik. Kelebihan dari simulasi juga mampu menangkap situasi yang sebenarnya (Okaya \& takahashi, 2011)

Berbeda dengan penelitian yang dilakukan oleh Widjanarko dan Minnafiah (2014) menyatakan bahwa tidak terdapat pengaruh pendidikan bencana terhadap kesiapsiagaan siswa, hal ini dikarenakan waktu pelaksanaan penelitian tidak terjadwal sehingga untuk mengevaluasi pertemuan sebelumnya kurang maksimal, selain itu waktu pelaksanaan yang tidak terjadwal menyebabkan anak mudah lupa dengan materi pelatihan sebelumnya. Penelitian oleh Widjanarko dan Minnafiah (2014) juga mengidentifikasi faktor usia berpengaruh pada daya serap materi penelitian. Menurut Herdwyanti dan Sudayono (2012) menyatakan bahwa anak usia sekolah memiliki kemampuan dan sumberdaya yang terbatas untuk mengontrol atau mempersiapkan diri ketika merasa takut sehingga sangat bergantung pada pihak-pihak di luar dirinya supaya dapat pulih kembali dari bencana. Penelitian Sabri (2014) didapatkan sekitar 25\% siswa SD masih memiliki pengetahuan kesiapsiagaan bencana yang masih rendah. Rendahnya kesiapsigaan anak menyebabkan anak akan sangat mudah masuk dalam kondisi rentan. Kerentanan anak-anak terhadap bencana dipicu oleh faktor keterbatasan pemahaman tentang risiko- risiko di sekeliling mereka, yang mengakibatkan tidak adanya kesiapsiagaan dalam menghadapi bencana. Selain itu menurut peneliti siswa belum pernah mengikuti kegiatan penginformasian kesiapsiagaan akan bencana yang dilakukan pihak sekolah

Pelatihan diberikan oleh BPBD bersama tim peneliti. Pelatihan diberikan dengan bahasa yang mudah dipahami oleh anak sekolah dasar, disertai dengan pemutaran video animasi dan simulasi (role play). Menurut BNPB (2012), pendidikan penanggulangan bencana dapat diberikan melalui pelatihan berupa ceramah dan simulasi. Hal ini didukung oleh pernyataan oleh Steward dan Wan (2007) dalam penelitiannya tentang peran simlasi didalam manajemen bencana dapat mengukur kesiapan seseorang dalam menghadapi bencana. Menurut Olson et al (2010) dalam penelitiannya juga menyatakan bahwa pendidikan tentang siaga bencana dengan menggunakan simulasi berupa game, permainan atau role play dapat memberikan hasil yang lebih baik dibandingkan yang tidak menggunakan simulasi.

Meningkatnya kesiapsiagaan siswa didukung oleh peran guru dan orang tua. Sekolah siaga bencana merupakan rencana tindak lanjut untuk menjadikan SDK Lere sebagai SD inklusi siaga bencana.
Pelatihan dan pemberikan edukasi terhadap guru dan orang tua siswa sebaiknya dilakukan terpadu dan berkelanjutan. Program sekolah siaga bencana meliputi program 6 bulan dan 9 bulan. Beberapa materi yang diajarkan dan kegiatan yang dilakukan antara lain: lokakarya pengurangan risiko bencana; pengenalan dan pembuatan peta evakuasi; pelatihan tanggap darurat; pengembangan sekolah yang aman; simulasi; pelatihan pengintegrasian pengurangan risiko bencana ke kurikulum sekolah dan metode pembelajaran PAKEM; peningkatan kapasitas guru dan siswa; pembuatan modul, film dan poster serta lomba sekolah bencana (World Vision Indonesia, 2011).

Hingga saat ini SDK Lere belum mengintegrasikan materi bencana dalam kurikulum muatan lokal, padahal lokasi sekolah ini sangat dekat dengan gunung berapi Egon. Dari beberapa riset sebelumnya mengidentifikasi adanya peningkatan kesiapsiagaan karena adanya pengintegrasian materi kebencanaan kedalam kurikulum. Menurut Prambudi (2017), menjelaskan pentingnya materi kebencanaan diintegrasikan dalam pendidikan anak sekolah dasar sebagai wujud pencegahan, peningkatan pengetahuan dan kesadaran terhadap bencana. Sejalan dengan pendapat dari Torany et.al (2019) tentang pentingnya pendidikan dalam bencana dan kondisi gawat darurat. SDK Lere selalu terkena dampak ketika gunung Egon erupsi karena hanya berjarak $3 \mathrm{~km}$ dari gunung Egon, hal tersebut dapat mengganggu proses belajar mengajar. Dalam hal ini peneliti berpendapat, bahwa dengan diberikannya pelatihan preparedness disaster gunung merapi dapat meningkatkan kesiapsiagaan siswa pada bencana yang rawan di daerah tersebut. Para siswa dan siswi akan mampu mengelolah resiko bencana dilingkungannya, akan adanya tindakan yang cepat dan tepat guna pada saat terjadi bencana dengan memadukan dan mempertimbangkan sistem penanggulangan bencana di daerah dan disesuaikan kondisi wilayah setempat, dengan begitu dapat meminimalisir korban dan kerugian akibat bencana tersebut. Pembentukan karakter siaga bencana harus dilakukan sejak dini ketika peserta didik masih berusia di bawah 12 tahun. Rentang usia yang tepat untuk menanamkan berbagai karakter baik bagi anak sebagai modal utama melahirkan generasi berkarakter di masa depan.

\section{SIMPULAN}

Pelatihan preparedness disaster meningkatkan kesiapsiagaan anak sekolah dasar dalam menghadapi bencana letusan gunung berapi 
Egon di SDK Lere.

Saran yang dapat diberikan bagi pihak sekolah yaitu dapat melaksanakan pelatihan siaga bencana dengan melibatkan semua pihak termasuk: guru, karyawan dan orangtua siswa. Selain itu materi tentang disaster preparedness perlu dimasukkan ke dalam kurikulum sekolah sebagai kurikulum muatan lokal.

\section{KEPUSTAKAAN}

American Academy of Pediatrics. 2008. Disaster Planning for Schools. Pediatrics, 122, 4.

Badan Nasional Penanggulangan Bencana (BNPB). 2014. Sebaran Kejadian Bencana dan Korban Meninggal per Jenis Kejadian Bencana 1815-2014. Jakarta.

Badan Nasional Penanggulangan Bencana, 2012. Peraturan Kepala BNPB No. 02 Tahun 2012 Tentang Pedoman Umum Pengkajian Risiko Bencana. Jakarta.

BNPB .2012. Pengembangan Kurukulum Dan Pelatihan Berbasis Kompetensi. Jakarta: BNPB.

BNPB .2017. Buku Pedoman Pelatihan Kesiapsiagaan Bencana, Membangun Kesadaran, Kewaspadaan Dan Kesiapsiagaan Dalam Menghadapi Bencana. Jakarta: BNPB.

Djafar I. M., Mantu F. N., \& Patellongi I. J. 2013. Pengaruh Penyuluhan Tentang Kesiapsiagaan Bencana Banjir Terhadap Pengetahuan dan Sikap Kepala Keluarga Di Desa Romang Tangaya Kelurahan Tamangapa Kecamatan Manggala Kota Makassar. http:// pasca.unhas.ac.id

Dodon. 2013. "Indikator dan Perilaku Kesiapsiagaan Masyarakat di Permukiman Padat Penduduk Dalam Antisipasi Berbagai Fase Bencana Banjir" .Jurnal Perencanaan Wilayah dan Kota, Vol. 24 No.2, Agustus 2013, Hal. 125-140. Bandung: Institut Teknologi Bandung.

Fitrianti N, I., Lilik, Z \& Suharsono, T (2019) Comparison of Simulation Method and Animation Video on Knowledge Related to Preparedness of Elementary School Students in Ternate, Indonesia. Indian Journal of Public Health Research \& Development.

Filina. 2013. Efektifitas Metode Role playing Untuk meningkatkan Kosakata Anak tunarungu. Jurnal Ilmu Pendidikan khusus, 1(1).

Herdwiyanti A. F \& Sudaryono. 2013. Perbedaan Kesiapsiagaan Menghadapi Bencana Ditinjau dari Tingkat Self-Efficacy pada Anak Usia Sekolah Dasar di Daerah Dampak Bencana Gunung Kelud. Jurnal Psikologi Kepribadian dan Sosial 2(1).

IFC. 2010. Disaster and Emergency Preparedness: Guidance for Schools. International Finance Corporation : World Bank Group.

Indriasari, F.N., 2014, Pengaruh Pelatihan Siaga Bencana Gempabumi terhadap Kesiapsiagaan Anak Sekolah Dasar dalam Menghadapi Bencana di Yogyakarta, Thesis: Universitas Gadjah Mada.

Khoirunisa, et al, 2014. Pengetahuan mahasiswa terhadap mitigasi bencana banjir setelah melakukan pembuatan lubang resapan bioporidi. Surakarta: Universitas Muhamadiyah Surakarta.

Listyaningsih, E dkk. 2010. Efektifitas Koordinasi Pelayanan Kesehatan Pengungsi Di Pos Pengungsian Maguwoharjo Pada Masa Tanggap Darurat Bencana Gunung Merpi Provinsi Daerah Istimewa Yogyakarta Tahun 2010. Naskah Publikasi Program Pascasarjana Fakultas Kedokteran Universitas Gajah Mada Yogyakarta.

MPBI. 2009. Pendidikan Siaga Bencana. http:// www.mpbi.org/content/pendidikansiagabencana. diakses: 18 September 2019.

Okaya, M., \& Takahashi, T. 2011. Evacuation simulation with communication for anti-disaster planning. 2011 IEEE International Symposium on Safety, Security, and Rescue Robotics.

Olson, D.K, Scheller, A, Larson, S, Lindeke, L \& Edwardson, S. 2010. Using Gaming Simulation to Evaluate Bioterrorism and Emergency Readiness Education. Public Health Rep, May-June 2010, 125, 468-477.

Prambudi. 2017. IntegratingDisaster Mitigation Education In the Elemntary School Curriculum. 1st International Conference on Social Sciences and Wetland Environment. ICSSE, 2017

Purwati, R.D., Bidjuni, H., Babakal, A. 2014, Pengaruh pelatihan terhadap 
pengetahuan perilaku klien hipertensi di Puskesmas Bahu Manado, Laporan Penelitian, Universitas Sam Ratulangi, Manado, 2(2).

Sabri. 2014. Pengaruh Pengintegrasian Materi Kebencanaan ke Dalam Kurikulum Terhadap Kesiapsiagaan Bencana Gempa Bumi dan Tsunami pada Siswa SD dan Menengah Di Banda Aceh. Tesis tidak dipublikasikan. Banda Aceh: Program Studi Magister Ilmu Kebencanaan Program Pascasarjana Universitas Syiah Kuala Darussalam Banda Aceh

Sanjaya, W. 2013. Strategi Pembelajaran: Berorientasi Standar Proses Pendidikan. Jakarta: Kencana Prenadamedia Group

Steward, D \& Wan, T.T. 2007. The Role of Simulation and Modeling in Disaster Management. J Med Syst. 3, 125-130.

Sudiharto. 2011. Manajemen Disaster. Badan Penegmbangan dan Pemberdayaan Sumber Daya Manusia dan Kesehatan. Departemen Kesehatan RI.

Torani, Majd, Maroufi, dowlaty \& Rahim Ali. 2019. The important ofEducation on disaster and emergencies: A review article. Journal of education and health promotion 8. 2019

Tuswadi, \& Hayashi, Takehiro.2014. Disaster Prevention Education in Merapi Volcano Area Primary Schools: Focusing on Students' Perception and Teachers' Abstract Performance. Paper presented at the The 4th International Conference on Sustainable Future for Human Security, Sustai 2013, Kyoto.

Widjanarko \& Minnafiah .2018.Pengaruh Pendidikan Bencana Pada perilaku Kesiapsiagaan Siswa .Jurnal Ecopsy. 5.

Wijayanti, Pipit .2012. Pemanfaatan Informasi Geospasial Tematik dalam Peningkatan Kapasitas Terhadap Bencana Berbasis Sekolah.

World Vision Indonesia. 2011. Sekolahku Siaga Bencana: Dokumentasi Program. PT Sinar Surya Megah 